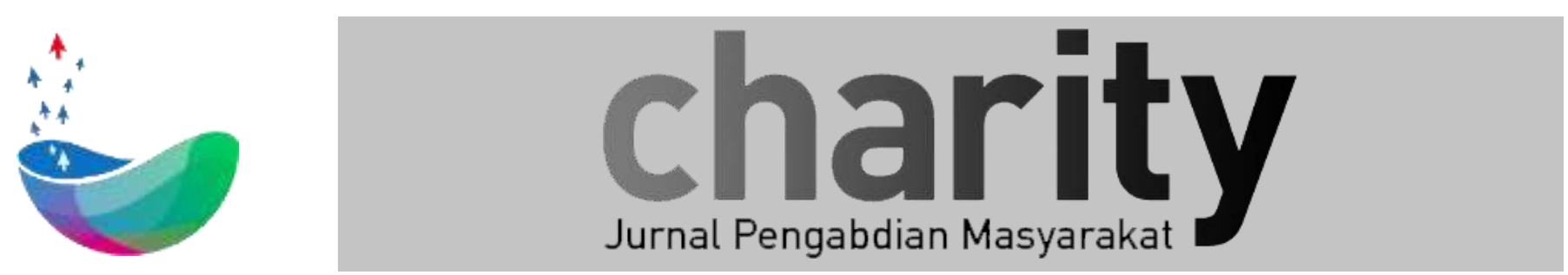

\title{
PEMBUATAN BAGAN WISATA UNTUK MENINGKATKAN PEREKONOMIAN NELAYAN DAN MELESTARIKAN POPULASI IKAN DI TELUK PELABUHAN RATU SUKABUMI 2017
}

\author{
Jondri $^{1}$, Deni Saepudin ${ }^{2}$, Putu Harry Gunawan ${ }^{3}$ \\ ${ }^{1}$ Universitas Telkom Bandung \\ ${ }^{2}$ Universitas Telkom Bandung \\ ${ }^{3}$ Universitas Telkom Bandung \\ *jondri@telkomuniversity.ac.id
}

\section{INFO ARTIKEL}

Diterima 3 November 2017

Direvisi 7 November 2017

Disetujui 16

November 2017

Tersedia Online 24

Oktober 2018

Keyword : bagan, wisata, rumpon, karamba

\section{ABSTRAK}

Bagan merupakan salah satu alat tangkap ikan yang digunakan oleh nelayan, termasuk para nelayan di Teluk Pelabuhan Ratu Sukabumi. Prinsip yang digunakan adalah memancing ikan untuk berkumpul dengan bantuan cahaya lampu pada malam hari dibawah bagan dan kemudian ditangkap dengan menggunakan jaring. Sekilas cara menangkap ikan seperti ini kelihatan menguntungkan, karena jumlah ikan yang bisa ditangkap bisa cukup banyak dan tidak perlu mengeluarkan bahan bakar untuk perahu. Tapi jika dilihat dalam perspektif jangka panjang, cara menangkap ikan seperti ini tidak ramah lingkungan. Karena ikan-ikan ukuran kecil juga ikut tertangkap dan dijual dengan harga yang murah. Selain harganya murah, stock ikan dilaut juga akan semakin berkurang. Dalam jangka panjang menangkap ikan dengan cara ini dapat merugikan nelayan.

Dengan semakin bertambahnya jumlah bagan yang ada di Teluk Pelabuhan Ratu dikhawatirkan akan berdampak buruk terhadap lingkungan, karena pada daerah lain sudah terjadi jumlah ikan yang bisa ditangkap setiap tahunnya menurun dengan bertambah banyaknya jumlah bagan. Untuk itu perlu diberikan alternatif pemanfaatan bagan, dengan tidak mengurangi nilai ekonomi yang bisa diperoleh nelayan.

Kegiatan pengabdian masyarakat yang dilakukan berupa pembuatan bagan wisata terpadu. Bagan wisata ini tidak dibuat dari awal, tapi dikonversi dari bagan konvensional milik nelayan. Pada bagan wisata ini akan dilengkapi dengan rumpon (tempat ikan berkembang biak dan berlingdung), karamba, tempat memancing, dan restoran yang diharapkan dapat menjadi alternatif wahana wisata bagi wisatawan yang berkunjung ke Pelabuhan Ratu.

\footnotetext{
Korespondensi :

Direktorat Penelitian dan Pengabdian Masyarakat, Universitas Telkom

Jl. Telekomunikasi No. 1, Terusan Buah Batu, Bandung, 40257

Indonesia.

E-mail: charity@telkomuniversity.ac.id

ORCID ID:

Penulis Pertama: -

https://doi.org/10.25124/charity.v1i01.1584

Paper_reg_number Charity0012010112 @ The Authors. Published by Directorate of Research and Community Service, Telkom University.

This is an open access article under the CC BY-NC 4.0 license (https://creativecommons.org/licenses/by-nc/4.0/)
} 


\section{PENDAHULUAN \\ 1.1 Latar Belakang}

Pemanfaatan sumber daya alam yang berkelanjutan, termasuk sumber daya ikan, harus menjadi perhatian semua pihak. Termasuk Program Studi Ilmu Komputasi Fakultas Informatika. Salah satu fokus kajian dari prodi Ilmu Komputasi adalah pembuatan model dan simulasi terhadap berbagai masalah dalam kehidupan sehari-hari. Pemodelan pemanfaatan sumber daya ikan secara berkelanjutan merupakan salah satu model dan simulasi yang sering digunakan dalam perkuliahan dan menjadi topik penelitian dosen.

Pelabuhan Ratu adalah ibukota Kabupaten Sukabumi yang terletak pada teluk pelabuhan ratu. Penggerak utama perekonomian masyarakat adalah sektor perikanan tangkap dan parawisata. Selama ini dua sektor unggulan ini dimanfaatkan secara terpisah. Ikan ditangkap dan dijual di Tempat Pelelangan Ikan (TPI) dan orang-orang berwisata dipantai. Untuk lebih meningkatkan nilai ekonomi dari potensi perikanan ini, dua sektor unggulan ini dapat digarap secara terpadu.

Teluk pelabuhan ratu kaya dengan sumber daya ikan serta lobster. Jenis ikan yang biasa ditangkap oleh nelayan adalah, layur, cakalang, tuna, berbagai jenis ikan demersal, tenggiri dan masih banyak jenis ikan yang lainnya. Alat tangkap yang digunakan bermacammacam, tergantung jenis ikan dan daerah tangkapannya seperti pancing, jaring, bagan dan bubu. Masing-masing alat tangkap mempunyai kelebihan dan kekurangan. Dari jumlah ikan yang bisa ditangkap, penggunaan jaring dan bagan dapat menghasilkan ikan yang lebih banyak dibandingkan menggunakan pancing dan bubu. Tapi penggunaannya dapat menyebabkan overfishing(penangkapan ikan yang berlebihan) jika tidak dibatasi dengan aturan yang ketat.

Penggunaan bagan secara masif dalam waktu yang lama dapat mempengaruhi stock ikan. Hal ini disebabkan karena bagan akan menjebak ikan-ikan, terutama ikan kecil, untuk berkumpul dengan bantuan cahaya lampu dan kemudian dijaring. Sehingga ikan tidak sempat berkembang biak. Harga jual perkilogram ikan-ikan kecil ini juga jauh lebih murah dibandingkan kalau ditangkap pada ukuran ekonomis mereka.

Setiap tahunnya ratusan ribu wisatawan mengunjungi Pelabuhan Ratu. Banyak objek wisata yang dapat dikunjungi, terutama wisata pantai, seperti pantai Karang Sari, Citepus, Karang Hawu, Cimaja dan Sawarna. Kegiatan utama yg dilakukan wisatawan adalah bermain diarea pantai dengan berbagai macam kegiatan seperti berenang, bermain bola, menikmati berbagai permainan seperti banana boat dan arung arus. Disamping itu para wisatawan juga dapat menikmati kuliner, khususnya seafood pada restoran atau warung yang banyak terdapat disekitar tempat wisata. Sangat sedikit sekali wisatawan yang melakukan kegiatan memancing dilaut. Hal ini disebabkan oleh mahalnya menyewa perahu untuk memancing disekitar teluk pelabuhan ratu.

Untuk lebih meningkatkan nilai ekonomi dari dua sektor ini dan mereduksi pengaruh buruk dari penggunaan bagan, dapat dilakukan dengan cara membuat bagan wisata. Dimana pada bagan ini wisatawan dapat melakukan kegiatan memancing ikan dan sekaligus menikmati ikan hasil tangkapannya. Karena pada bagan wisata ini akan dilengkapi dengan rumpon, karamba, tempat memancing dan perahu. Bagan wisata ini tidak dibuat dari awal, tapi dimodifikasi dari bagan konvensional milik nelayan yang sudah dibeli. Pengelolaan bagan wisata ini akan diserahkan pada Lembaga Swadaya Masyarakat (LSM) Komunitas Lingkar Hijau dengan melibatkan nelayan sebagai pekerja. LSM Komunitas Lingkar Hijau akan mengelola pemasaran dan pembukuan hasil pemasukan. Nelayan akan bertindak sebagai pekerja pada bagan yang bertugas untuk menjaga bagan dan menemani para wisatawan. Pada saat wisatawan tidak ada, nelayan tersebut masih bisa menangkap ikan 
dibagan dengan menggunakan pancing. Sehingga diharapkan penghasilan nelayan akan lebih besar dibandingkan jika bagannya hanya berfungsi sebagai alat tangkap ikan.

\subsection{Tujuan dan Manfaat Kegiatan}

Tujuan kegiatan pengabdian masyarakat ini adalah

a. Membangun bagan wisata di Teluk Pelabuhan Ratu

b. Meningkatkan penghasilan nelayan pengelola bagan wisata

Adapun manfaat kegiatan ini bagi mitra pengabdian masyarakat adalah :

Bagi mitra 1 LSM Komunitas Lingkar Hijau, bagan wisata ini dapat menjadi pilot project pemanfaatan sumber daya perikanan yang berkelanjutan. Karena dengan konsep bagan wisata ini nilai ekonomis dari ikan akan sangat tinggi. Nilai ekonomis ikan tidak hanya dihitung dengan berapa harga ikan perkilogram tapi dengan beragam kegiatan yang dapat menghasilkan nilai tambah ekonomi, seperti penyewaan alat pancing dan restoran apung.

Disamping itu, ketersediaan ikan disekitar bagan akan tetap terjaga, karena ditangkap hanya dengan menggunakan pancing. Sehingga dengan kegiatan pengabdian masyarakat ini dapat menjadi contoh agar bagan konvensional dapat dikonversi menjadi bagan wisata.

Bagi mitra 2 kelompok nelayan pekerja bagan dan nelayan perahu kecil diharapkan penghasilannya akan semakin meningkat. Karena disamping akan diberi gaji dari hasil pengelolaan bagan wisata, nelayan tersebut juga bisa menangkap ikan pada bagan wisata. Kegiatan ini bisa dilakukan pada saat tidak ada wisatawan yang mengunjungi bagan. Penangkapan ikan hanya diperbolehkan menggunakan pancing saja.

\section{MASALAH}

Persoalan utama yang dihadapi oleh nelayan, baik nelayan penangkap ikan dengan perahu kecil maupun nelayan bagan apung, adalah ketidakpastian hasil yang diperoleh tiap melaut. Sementara biaya yang mereka keluarkan selalu tetap untuk setiap pergi melaut, seperti biaya bahan bakar, biaya umpan dan biaya makanan. Sehingga tidak jarang mereka terjerat hutang kepada rentenir.

Khusus untuk nelayan bagan apung, masalah lain yang dihadapi adalah tingginya jumlah ikan yang tertangkap bukan ikan sasaran (by cacth). Dari penelitian yang telah dilakukan oleh Yuda, L.K dan Khan, A.M.,( 2012), diperoleh kesimpulan alat tangkap bagan apung kurang ramah lingkungan karena ikan yang tertangkap lebih banyak didominasi oleh ikan belum dewasa $(56,44 \%)$ dan dan bukan ikan tujuan utama $(45,33 \%)$.

\section{METODE}

Untuk membantu nelayan mengatasi masalah diatas diperlukan penambahan fungsi dari bagan apung dan perahu nelayan sehingga bisa digunakan untuk melayani wisatawan. Tahapan pelaksanaan pengabdian masyarakat ini adalah :

1. Menambahkan rumpon yang terbuat dari pelepah kelapa yang diikat dengan tali nilon dan diberi pemberi pemberat. Rumpon ini berfungsi sebagai pemikat ikan kecil untuk berkumpul dibawah bagan apung. Ikan-ikan kecil akan menjadi mangsa dari ikan predator besar yang mempunyai nilai ekonomi tinggi. Selanjutnya ikan-ikan besar ini akan menjadi magnet bagi wisatawan untuk datang ke bagan apung, baik untuk kegiatan memancing maupun spearfishing.

2. Merapikan bagian atas bagan apung sehingga nyaman bagi wisatawan yang akan melakukan aktifitas memancing diatas bagan apung. Hal pertama yang dilakukan adalah menambahkan tangga untuk naik keatas bagan apung dari perahu. Berikutnya menambahkan bambu pada 
lantai bagan apung sehingga lantainya nyaman untuk diinjak dan membuat atap pada sebagian bagan apung yang akan menjadi tempat memancing.

3. Melengkapi perahu nelayan dengan peralatan keselamatan wisatawan berupa jaket pelampung. Menambah atap pada perahu nelayan sehingga nyaman bagi wisatawan.

Untuk pemasaran bagan apung dan perahu wisata akan dilakukan melalui media sosial, terutama grub hobi pemancing dan spearfishing.

Kegiatan pengabdian masyarakat dilaksanakan di kelurahan Palabuhanratu Sukabumi. Kegiatan ini dilaksanakan secara multiyears, dari tahun 2015 sampai dengan tahun 2017.

\section{ANALISA KEGIATAN}

Kegiatan ini dilakukan dalam tiga tahun. Pada tahun pertama dilakukan konversi 1 buah bagan konvensional menjadi bagan wisata yang dilengkapi dengan rumpon. Rumpon berfungsi sebagai pemikat ikan-ikan kecil untuk berkumpul dibawah bagan. Ikan-ikan kecil ini akan menjadi magnet bagi ikan pelagis besar seperti tenggiri, wahoo, dorado dan tuna untuk berkumpul dibawah bagan. Pada akhirnya ikan pelagis besar ini akan menjadi daya tarik bagi wisatawan untuk berkunjung ke bagan wisata, baik untuk mancing maupun spearfishing. Gambar bagan konvensional dan rumpon dibawah bagan dapat dilihat pada gambar 1

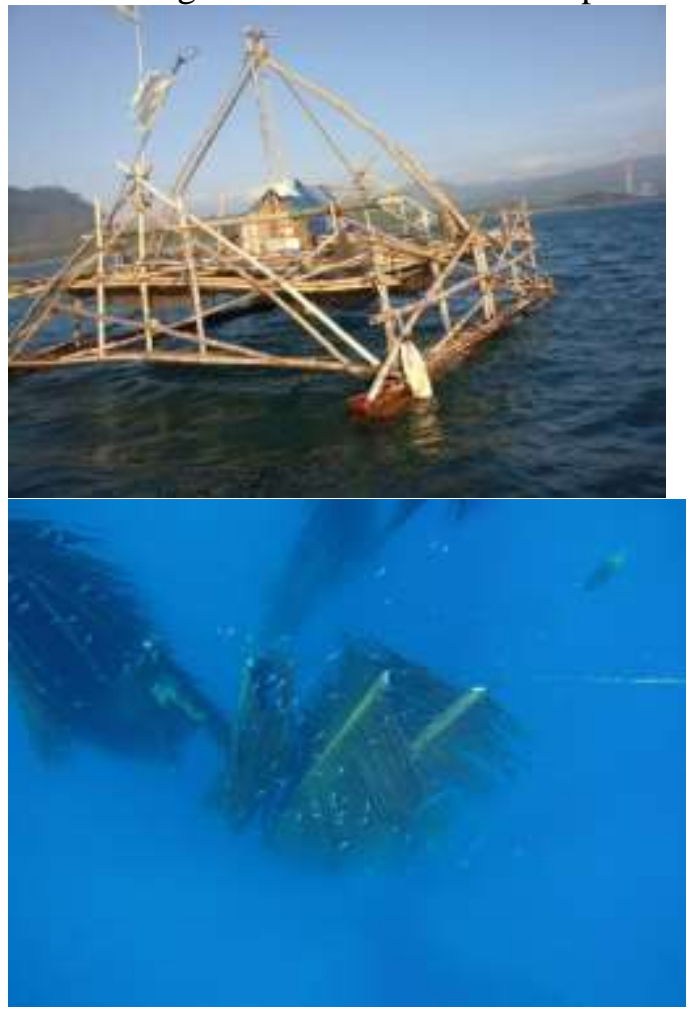

Gambar 1 Bagan konvensional dan rumpon dibawah bagan

Pada tahun kedua bagan wisata dilengkapi dengan karamba tempat memelihara ikan dan tempat mancing yang lebih representatif. Karamba berfungsi untuk menyimpan ikan-ikan kecil yang tertangkap untuk dipelihara. Ikan ini akan digunakan untuk pengunjung bagan wisata yang tidak mendapat ikan. Gambar bagan wisata yang dilengkapi karamba dapat dilihat pada gambar 2 dan gambar 3. 


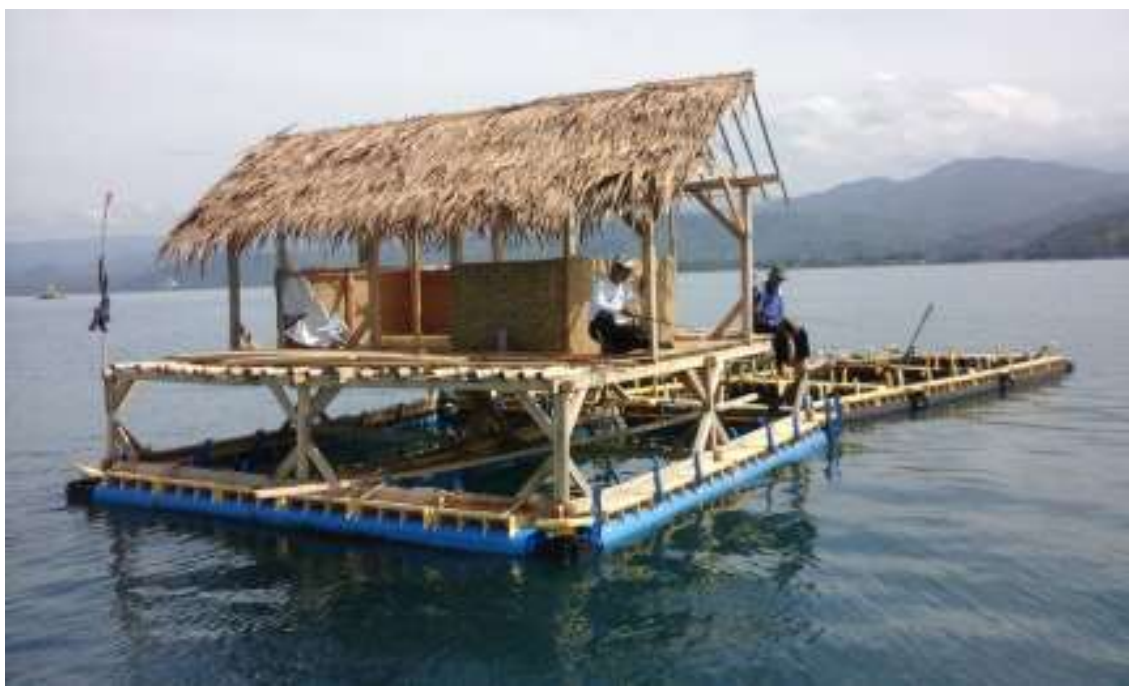

Gambar 2 Bagan wisata tahun kedua yang dilengkapi karamba dan tempat mancing

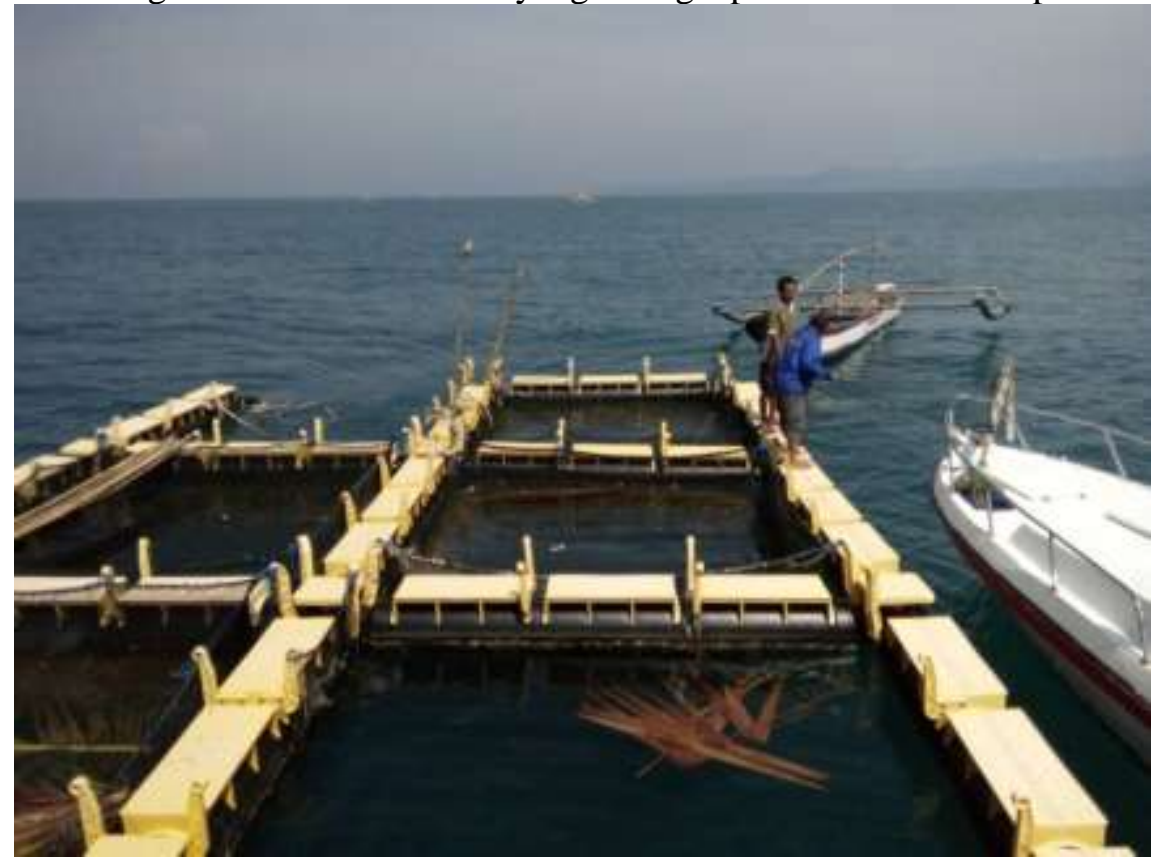

Gambar 3 Karamba didepan bagan

Pada tahun ketiga bagan wisata dilengkapi dengan perahu sebagai alat transportasi dari dermaga ke bagan. Selain itu perahu juga dapat digunakan sebagai alat transportasi untuk disewa oleh wisatawan yang akan berkunjung ke Geopark Ciletuh melalui jalur laut. Gambar perahu yang diberikan kepada nelayan dapat dilihat pada gambar 4. 


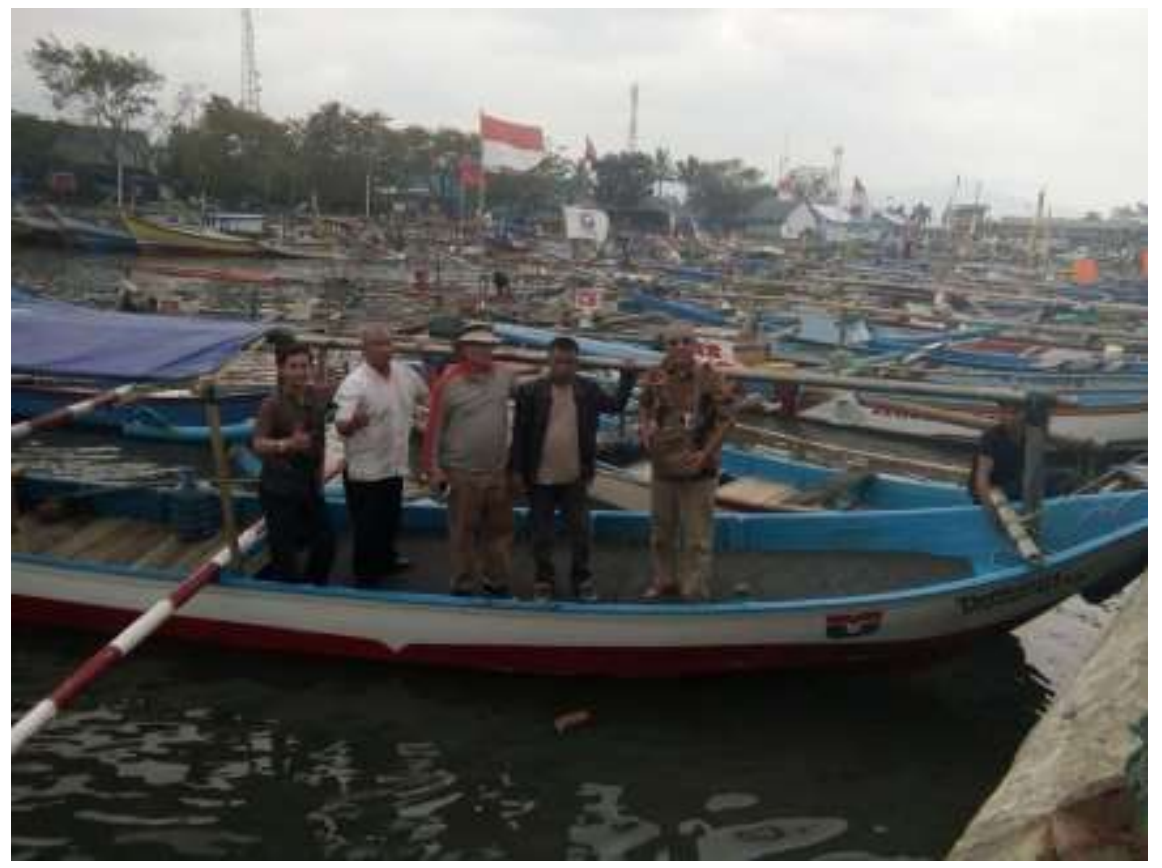

Gambar 4 Perahu bantuan untuk transportasi dari dermaga ke bagan

Kendala yang muncul dalam pelaksanaan pengabdian masyarakat ini dapat dikelompokkan menjadi dua, yaitu kendala dari alam dan kendala dari manusia. Kendala dari alam adalah musim barat yang menyebabkan ombak besar yang bisa memutuskan tali jangkar bagan. Kendala ini bisa diatasi dengan cara menambah tali jangkar atau memindahkan bagan ketempat yang aman untuk sementara. Kendala dari manusia berasal dari nelayan yang menggunakan jaring (nelayan payang). Nelayan payang sering memutuskan tali bagan dengan tujuan untuk menjaring ikan-ikan yang berkumpul dibawah bagan. Untuk meminimalisir gangguan ini dilakukan komunikasi yang intensif terhadap nelayan payang tentang pentingnya manfaat yang akan diperoleh oleh keseluruhan nelayan dari kegiatan pengabdian masyarakat ini.

\section{KESIMPULAN DAN SARAN}

Kegiatan pengabdian masyarakat pembuatan bagan wisata untuk meningkatkan perekonomian nelayan dan melestarikan populasi ikan di teluk Pelabuhan Ratu Sukabumi ini terlaksana sesuai dengan rencana, yaitu membuat bagan wisata dan melengkapinya dengan rumpon, karamba dan perahu pendukung. Dengan adanya bagan wisata dan perahu untuk mengangkut wisatawan ini, nelayan dapat berfungsi sebagai operator wisata. Sehingga mereka mendapatkan penghasilan yang pasti. Disamping itu nelayan masih dapat menangkap ikan dirumpon dengan menggunakan pancing dan hasilnya dijual kepelelangan ikan jika tidak ada wisatawan. Sehingga keberadaan pengabdian masyarakat ini dapat meningkatkan perekonomian nelayan, sekaligus melestarikan sumber daya ikan di teluk Pelabuhan Ratu. Untuk kegiatan pengabdian masyarakat selanjutnya dapat dilakukan transpalasi terumbu karang di teluk Pelabuhan Ratu, sehingga bisa menjadi alternatif tempat wisata yang bisa dikunjungi selain bagan wisata. 


\section{DAFTAR PUSTAKA}

1. Yuda, L.K. and Khan, A.M., 2012. Tingkat keramahan lingkungan alat tangkap bagan di perairan Palabuhanratu, Kabupaten Sukabumi. Jurnal Perikanan Kelautan, 3(3)

2. Nurhayati, A., 2013. Analisis Potensi Lestari Perikanan Tangkap di Kawasan Pangandaran. Jurnal Akuatika, 4(2). 